\title{
Psicanálise e Ética: uma Reflexão
}

\author{
Psychoanalysis and ethics: a reflection
}

KEHL, Maria Rita. Sobre Ética e Psicanálise. Companhia das Letras, São Paulo, 2009, 208 pág., ISBN: 9788535902211, R\$ 44,50.

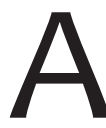
autora da obra Sobre ética e psicanálise procura refletir sobre qual contribuição a psicanálise traria para uma ética na contemporaneidade e, ao mesmo tempo, questiona o sentido de se pedir justamente à psicanálise o estabelecimento de critérios para o advento de uma ética contemporânea, dado o momento atual no qual ela é questionada e criticada pelo fato do processo de sua terapia ser lento, bem como por insistir na existência do conflito no cerne da constituição do sujeito e na produção de seus sintomas.

A constatação de uma crise ética mundial desencadeia alarmantes sintomas sociais e a necessidade de respostas. Maria Rita Kehl situa essa crise ética no problema do reconhecimento da lei e na desmoralização do código. O referido problema diz respeito à lei universal que impõe uma renúncia ao excesso de gozo na forma da interdição do incesto, sendo essa lei, cujo reconhecimento se situa numa origem mítica e não se refere aos códigos legais e morais das nações, que delimita e legitima a existência social. As sociedades modernas têm se mantido por meio da afirmação do narcisismo individual. Além disso, existe um modo de alienação no cerne do laço social orientado para o gozo e o consumo e, em razão desse processo, o indivíduo acredita ser autônomo, sem compromisso com seus antepassados e sente dificuldade em reconhecer o peso do vínculo com seus semeIhantes para sustentar sua posição subjetiva. Portanto, a crise do reconhecimento da lei é uma dificuldade do reconhecimento da dívida simbólica com seus antepassados e com a coletividade. Assim, a lei do imperativo da renúncia ao gozo estaria perdendo a sua sustentação simbólica diante da lógica do capital movido pelo apelo ao gozo. Segundo a autora, o apelo contemporâneo ao gozo dificulta o reconhecimento da lei, ou seja, impõe a dificuldade de reconhecer que o gozo pleno é impossível e que o apelo moderno à sua busca constante produz mais angústia e mais violência. Quanto à desmoralização do código, Kehl o situa na perda do apogeu e da cultura de valores burgueses à qual Freud atribuiu à rigidez de costumes e a produção do sofrimento neurótico. O código tem uma autoria e precisa se tornar consensual e quando tem eficácia simbólica máxima dispensa explicações sobre os seus postulados. Nesse sentido, a autora afirma

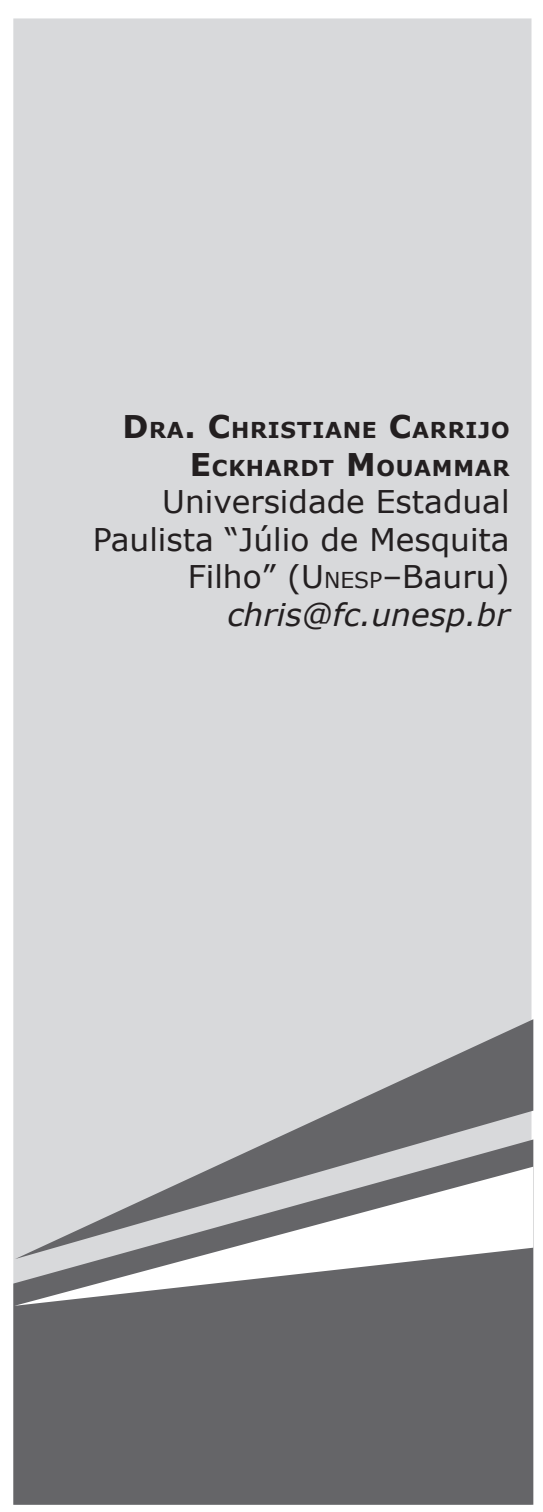


que quando se pergunta as causas de um código é porque sua sustentação simbólica já se esgotou por existirem outros discursos circulando na sociedade, representando outros tipos de pactos sociais.

Para Kehl, o laço social, em nossa sociedade, é quase exclusivamente mediado pela mídia eletrônica e, logo, a relação com o semelhante está dominada e reduzida por formações imaginárias. O homem estaria correndo o risco de ficar reduzido à sua dimensão de imagem e a sociedade do espetáculo, dominada por formações imaginárias, estaria organizada num apelo ao eu narcísico por meio de identificações e das demandas de amor e reconhecimento. No espetáculo, os afetos são mobilizados e o pensamento é dispensado, não sendo possível fundar uma ética sobre os "bons" ou "maus" afetos. Se a psicanálise é convidada a responder a essa crise ética, ela terá de fazê-lo levando em consideração que ela é uma prática da dúvida e um método investigativo e, portanto, não traz certezas, e não é uma filosofia propositiva.

Uma das formas pelas quais a psicanálise foi absorvida pela cultura e se propõe a trazer respostas para o sofrimento e a crise ética é pela tentativa de explicar as neuroses e os complexos inconscientes como a origem do mal e da infelicidade e, sua contrapartida, a afirmação de uma felicidade para quem conhece e está em paz com seu inconsciente. A outra forma em que a psicanálise é convidada a trazer respostas para o sofrimento e a crise ética é trabalhar com a circulação da palavra, tentando escutar e acolher os efeitos que ela produz nos indivíduos e na sociedade. Sai de cena a psicanálise que a tudo explica e entra em cena a psicanálise da pergunta que não quer cessar e que convida a todos a suportar a angústia da indagação. Para o inconsciente o mal não existe e a moral não importa, contudo isso não nos autoriza a nos tornarmos imorais, porque essa constatação psicanalítica deveria fazer com que fôssemos mais tolerantes com os defeitos alheios e mais humildes em relação às nossas qualidades. Assim, o desejo é indiferente à ética e, por isso se conclui a impossibilidade de uma ética ser fundada com base nas razões inconscientes. Contudo, se a psicanálise descobriu o campo do inconsciente, ela pode ser convidada a dizer algo sobre a covardia moral do neurótico que se recusa a se responsabilizar pelo seu desejo.

Kehl afirma que a psicanálise poderia apontar caminhos para a ética, mas não dar uma resposta pronta. Um desses caminhos seria que o sujeito não tem culpa das produções do seu inconsciente, porém, o sujeito pode responder com responsabilidade sobre ele, e esta responsabilidade seria como uma solução de compromisso entre o sujeito e o seu desejo, seria o oposto da culpa neurótica. Nesse caso, a passagem de um indivíduo por uma análise, com vistas ao reconhecimento da existência do seu inconsciente e do desejo, seria imprescindível para torná-lo mais responsável pelo desejo que o habita e para evitar sintomas pessoais e as projeções no outro daquilo que é negado em si mesmo.

O compromisso da psicanálise pode, então, ser visto em fazer a palavra circular, poder dizer do compromisso do sujeito com o seu desejo e aceitar a falta e o conflito como inerentes ao humano e ser esse homem que aceita a responsabilidade pelo seu desejo. Segundo a autora, a ética que pode ser fundada nas contribuições da psicanálise é uma ética da clínica psi- 
canalítica, pois a partir dela ficou estabelecido o drama humano da liberdade e da alienação ao inconsciente e de como o sujeito freudiano só é livre quando aceita a existência do inconsciente que o habita e que, em parte, sempre será estranho ao eu. Como, por esse lado, a psicanálise não pode propor uma verdade definitiva para a natureza humana, o que ela pode apontar é a necessidade de entender quais condições sociais estão produzindo a crise ética atual. A psicanálise vem para interrogar o homem nas suas dimensões de liberdade e conflito, vem fazer análise crítica das condições sociais estabelecidas, vem questionar as verdades apontadas como únicas e dar a palavra aos que querem falar. A palavra é a condição da existência de todas as civilizações; ela é, de acordo com a autora, aquilo que reinterpretamos para o humano, o fato inelutável de que existe o outro.

A psicanálise está ao lado da invenção e, conforme defende Kehl, se ela pode propor um valor para a modernidade, este é a alteridade, a aceitação do outro em sua semelhança na diferença, sendo essa aceitação a base para a construção de uma ética para os tempos atuais.

DADOS DA AUTORA:

Dra. Christiane Carrijo Eckhardt Mouammar

Professora do Departamento de Psicologia - UNESP - Bauru. Mestre em Psicologia Clínica - PUC-SP. Doutora em Filosofia - UFSCar.

Recebido: 08-02-2012

Aprovada: 20-03-2012 